\title{
Bacterial Secretome Analysis in Hunt for Novel Bacteriocins with Ability to Control Xanthomonas citri subsp. Citri
}

\author{
Dariush Gholami 1, 2, Tannaz Goodarzi 1, Saeed Aminzadeh 1,“, Seyed Mehdi Alavi 1, Nasrin Kazemipour 3, \\ Naser Farrokhi 4 \\ ${ }^{1}$ Department of Bioprocess Engineering, National Institute for Genetic Engineering and Biotechnology, Tehran, Iran \\ ${ }^{2}$ Science Department, Sistan-Baluchistan University, Zahedan, Iran \\ ${ }^{3}$ School of Veterinary Medicine, Shiraz University, Shiraz, Iran \\ ${ }^{4}$ Department of Biotechnology, Faculty of New Technologies and Energy Engineering, Shahid Beheshti University, Tehran, \\ Iran
}

${ }^{*}$ Corresponding author: Saeed Aminzadeh, National Institute for Genetic Engineering and Biotechnology, Tehran, Iran. Tel: +98-2144787412; Fax: +982144787399; E-mail: aminzade@nigeb.ac.ir

Received: January 07, 2015; Revised: June 27, 2015; Accepted: August 27, 2015

Background: Xanthomonas citri subsp. citri (Xcc), the causative agent of bacterial citrus canker, has affected citriculture worldwide. Varieties of means have been used to minimize its devastating effects, but no attention has been given to bacteriocins.

Objectives: Here and for the first time, we report the isolation and characterization of two novel bacteriocins.

Materials and Methods: Secretome containing bacteriocins of isolated bacteria was separated via SDS-PAGE. Each isolated protein band was characterized and checked for its efficacy in controlling two pathogenic isolates of Xcc via disk diffusion assay. The effects of varieties of carbon, nitrogen and phosphate sources were evaluated on both bacterial growth and bacteriocin production via Taguchi orthogonal method.

Results: The two bacteriocins showed an activity up to $55^{\circ} \mathrm{C}$ that were sensitive to proteases suggesting being protein in nature. Analysis of SDS-PAGE purified protein bands of bacterial secretomes with demonstrated potency against Xcc revealed the presence of peptides with relative molecular masses of 16.9 and $17 \mathrm{kDa}$ for Cronobacter and Enterobacter, respectively. Sequence analysis of peptides revealed an HCP1 family VI secretion system homologue for Cronobacter (YP_001439956) and pilin FimA homologue for Enterobacter (CBK85798.1). A Taguchi orthogonal array was also implemented to determine the effect of temperature and eight other chemical factors on bacteriocin production for each bacterium.

Conclusions: Two peptides with novel antibacterial activities effective against Xcc were isolated, characterized and conditions were optimized for their higher production.

Keywords: Bacteriocin; Biocontrol; Protein sequencing; Taguchi orthogonal array; Xanthomonas citri

\section{Background}

Bacterial phytopathogens affect the well-being of plants, reducing the quality and in severe cases quantity of produce. Use of resistant cultivars, antibiotics and chemicals next to the eradication of infected plants in case of quarantine bacterial diseases are amongst many approaches that usually are being considered to suppress their negative impact in agriculture. Nevertheless, a combination of less agrochemical and more biological control methods next to the use of resistant cultivars, so called integrated disease management system (IDMS), would be more beneficial to the environment, health and agricultural production. Use of microbial exudates including but not limited to antibiotics, proteinaceous exotoxins, lysozymes, and bacteriocins (1) may reduce the population of bacterial pathogens during seasonal outbreak.

Ribosomally synthesized antimicrobial peptides also known as bacteriocins with detrimental effect on limited bacterial host range can play an important role in the biocontrol of plant pathogenic bacteria species $(2,3)$. Thus far, out of 2254 identified antibacterial peptides from a range of organisms, 167 peptides are from bacterial sources (http://aps.unmc.edu/AP/database/antiB.php, 07/24/2103; 4). Of which only 9 antibacterial peptides are from gram negative bacteria, namely from Serratia plymuthica and Escherichia coli (5-13). 
Here and for the first time, an effort put towards identification of bacterial species that have the capability of inhibiting the growth of Xanthomonas citri subsp. citri $(X c c)$. Additionally, the bacterial secretomes were surveyed in order to pinpoint the possible anti-Xcc factors that can be considered as bacteriocins. The findings may have some implications in direct use of the bacterial species in nature to control Xcc population, if no other harms to be associated with these species. Following isolation of bacteriocins, the bacterial culture media were optimized towards faster bacterial growth and higher bacteriocin production. For this purpose and in order to avoid Factorial experiments with multifaceted combinations of factors, Taguchi orthogonal array method was used to obtain the same data with fewer experiments $(14,15)$.

\section{Materials and Methods}

\subsection{Bacterial and Bacteriocin Isolation}

Citrus plant parts, leaves, fruits, and branches, either healthy or with canker symptoms, and soil were collected from different locations of SistanBaluchistan province, Iran. The plant parts were surface sterilized with $70 \%(\mathrm{v} / \mathrm{v})$ ethanol once, ground to small pieces and added to Falcon tubes containing $2 \mathrm{ml}$ nutrient broth (NB, pH 6.5). Similarly and in order to keep even less-populated bacterial species in our collected samples, $0.1 \mathrm{~g}$ of soil was added to NB. The samples were incubated at rotary shaker $(180 \mathrm{rpm})$ at $37^{\circ} \mathrm{C}$ for $24 \mathrm{~h}$. The bacterial cells were collected from the supernatant after centrifugation at $7000 \times \mathrm{g}$ for 7 min at $22^{\circ} \mathrm{C}$. The cells $(100 \mu \mathrm{L})$ were plated on nutrient agar and incubated at $37^{\circ} \mathrm{C}$ for $24 \mathrm{~h}$. Single clones (500) were isolated via few rounds of subculture and used for their controlling efficiency against Xcc (21 Iranian isolates and 3 international strains, namely LMG-9322, LMG-9671 and CFBP-3369) via disk diffusion assay. Paper filters were punched into circular pieces and layered on plates with bacterial cells already spread on. The secretomes were spotted on filters and the growth of bacterial cells was monitored.

In order to isolate secretomes containing bacteriocins, selected isolates $(5 \mu \mathrm{L})$ with inhibitory effect on $X c c$ were cultured in NB and centrifuged at $1000 \times \mathrm{g}$ for $10 \mathrm{~min}$. Supernatant passed through 0.2 micron biological filter to avoid any bacterial cells and $1 \mathrm{mM}$ PMSF was added. The supernatants were concentrated using Amicon ultra-4 centrifugal filters with $10 \mathrm{kDa}$ cutoff size (Millipore, MA, USA) at $4500 \times \mathrm{g}$ and stored at $4^{\circ} \mathrm{C}$.

\subsection{Bacterial Characterization}

Bacterial isolates with antagonistic activities against $X c c$ were characterized via sequence analysis of 16s rDNA. DNA was isolated using DNA isolation kit (Bioneer, Daejeon, Republic of Korea) according to the manufacturer. Isolated DNA was used as template for PCR amplification of $16 \mathrm{~s}$ rDNA using forward ( $5^{\prime}$ GAGTAATGTCTGGGAAACTGCCTG-3') and reverse (5'-CCAGTTTCGAATGCAGTTCCCAG- $3^{\prime}$ ) primers. PCR was initiated at $94^{\circ} \mathrm{C}$ for $5 \mathrm{~min}$, followed by 35 cycles of $\left[94^{\circ} \mathrm{C}: 30 \mathrm{~s} ; 57^{\circ} \mathrm{C}: 45 \mathrm{~s} ; 72^{\circ} \mathrm{C}: 90 \mathrm{~s}\right]$ and a final $72^{\circ} \mathrm{C}$ for $5 \mathrm{~min}$ in a $25 \mu \mathrm{L}$ reaction containing $2.5 \mu \mathrm{L}$ $10 \times$ PCR buffer, $25 \mathrm{mM} \mathrm{MgCl}_{2}(1.5 \mu \mathrm{L}), 5 \mathrm{mM}$ dNTPs $(1 \mu \mathrm{L})$ and 20 pmoles of each of primers. The PCR product was purified using High Pure PCR purification kit (Roche, USA) according to the manufacturer. The amplicon was sequenced at Source Bioscience (England) and phylogentic tree was constructed using MEGA 5.1 Beta4 (16). In addition to sequence analysis, biochemical characteristics of bacterial isolates were determined using Indol, methyl red, VogesProskauer (VP), $\mathrm{H}_{2} \mathrm{~S}$, citrate, urea, gelatin, glucose, xylos, lactose, manitol, arabinose, sorbitol, orthonitrophenyl- $\beta$-galactoside (ONPG) and ornithine decarboxylase. Moreover, the bacterial movement was tested.

\subsection{UV Effect on Bacteriocin Production}

Cultures of selected bacterial isolates $(50 \mu \mathrm{L})$ with the ability to inhibit $X c c$ growth were poured on petri dishes and pulsed with $320 \mathrm{~nm}$ UV light for $4 \times 30 \mathrm{~s}$. The plates were incubated for $1 \mathrm{~h}$ at $22^{\circ} \mathrm{C}$ and centrifuged at $7000 \times \mathrm{g}$ for $10 \mathrm{~min}$. The supernatant was filtered through 0.2 micron filter and disk diffusion assay was carried out to establish the possible effect of UV on bacteriocin production.

\subsection{Analysis of Bacterial Secretome}

The supernatant content was separated via SDSPAGE according to Laemmli (17) and non-stained protein bands according to the adjacent lane that is stained with Coomassie Brilliant Blue R-250 (Merck, NJ, USA) were excised from the gel. The gel pieces were incubated in $4.5 \%(\mathrm{v} / \mathrm{v})$ Triton $\mathrm{X}-100$ for $1 \mathrm{~h}$, washed twice with PBS for 2 min each and incubated in PBS on a rotary shaker for $1 \mathrm{~h}$ at $35^{\circ} \mathrm{C}$. PBS buffer was replaced and washed with $250 \mathrm{mM}$ Tris buffer $(\mathrm{pH}$ 7.0) three times, subsequently $20 \mathrm{mM}$ Tris buffer $(500$ $\mu \mathrm{L})$ was added and each tube was sonicated in cold water-bath (6 pulses of $50 \mathrm{~V}$ for $30 \mathrm{~s}$ each). Sephadex $\mathrm{G} 75$ was used to separate each protein band $(1.5 \mathrm{~mL})$ 
from the gel content at $500 \times \mathrm{g}$ for $10 \mathrm{~min}$.

Each isolated protein band was checked for its efficacy in controlling two pathogenic isolates of Xcc via disk diffusion assay as stated above. The bands with antibacterial effects were further characterized by incubation in a range of temperatures $(25,35,45,55,75,90,95,100$, 110 and $130^{\circ} \mathrm{C}$ ) and treatment with $25 \mathrm{mg} \cdot \mathrm{mL}^{-1}$ filtered trypsin, pepsin, proteinase $\mathrm{K}$ and papain for $30 \mathrm{~min}$. Furthermore, bacteriocins were incubated in buffers (1:2) with $\mathrm{pH}$ range of 3-10 for $1 \mathrm{~h}$. Detergents $(1 \%(\mathrm{v} / \mathrm{v})$ of Triton X-100, Tween 20 and Tween 80) and solvents $(1 \%(\mathrm{w} / \mathrm{v})$ of sodium dodecyl sulfate (SDS), ethylene diamine tetra acetic acid (EDTA) and $\mathrm{NaCl}$ ) were added to bacteriocins and incubated for $30 \mathrm{~min}$. Subsequent to all above treatments a disk diffusion assay was performed against Xcc.

The single protein isolates with positive reaction to $X c c$ were used in de novo peptide fingerprinting using Ultraflex III MALDI-TOF/TOF (Bruker Diagnostics Inc., UK) available at University of York, England

\subsection{Optimization of Bacterial Growth Condition and Improvement of Bacteriocin Production}

Initially the effects of varieties of carbon (glycogen, chitin, starch, polygalacturonic acid, sucrose, lactose, maltose, galactose, mannose, arabinose, glucose, fructose), nitrogen $\left(\mathrm{NH}_{4} \mathrm{Cl},\left(\mathrm{NH}_{4}\right)_{2} \mathrm{SO}_{4},\left(\mathrm{NH}_{4}\right)_{2} \mathrm{HPO}_{4}\right.$, $\left.\mathrm{NH}_{4} \mathrm{NO}_{3}, \mathrm{CH}_{3} \mathrm{COONH}_{4}\right)$ and phosphate $\left(\mathrm{KH}_{2} \mathrm{PO}_{4}\right.$, $\left.\mathrm{K}_{2} \mathrm{HPO}_{4}, \mathrm{Na}_{2} \mathrm{HPO}_{4}, \mathrm{NaH}_{2} \mathrm{PO}_{4}\right)$ sources $(1 \% \mathrm{w} / \mathrm{v})$ were evaluated on both bacterial growth (represented as $\mathrm{OD}_{600}$ ) and bacteriocin production (represented as halo diameter in $\mathrm{mm}$ via disk diffusion method) via Taguchi orthogonal analysis (14). Each experiment was repeated trice. Each source was added individually to $\mathrm{LB}$, autoclaved at $121^{\circ} \mathrm{C}$ for $20 \mathrm{~min}$, except for monosaccharaides that were filter sterilized. Since proper controls were considered for the experiment, differential data of carbon, nitrogen and phosphate sources available in LB were collected as the effect of the added sources. Each separate medium was inoculated with $2 \%(\mathrm{v} / \mathrm{v})$ of bacterial culture and incubated at $35^{\circ} \mathrm{C}$ with a constant shake at $180 \mathrm{rpm}$ for $24 \mathrm{~h}$. The bacterial growth in each medium was stopped by putting the culture tube on ice and growth was measured spectrophotometrically at $600 \mathrm{~nm}$ after $24 \mathrm{~h}$. From each growth medium, $5 \mathrm{~mL}$ of culture was centrifuged at $8000 \times \mathrm{g}$ for $10 \mathrm{~min}$ and supernatant was filtered using 0.2 micron filter to avoid any bacterial cell intrusion. The filtrate $(10 \mu \mathrm{L})$ was added to each paper disk and the disk was layered over NA plate with Xcc spread evenly on NA. The halo diameter (mm) was measured after the incubation of plates at $35^{\circ} \mathrm{C}$ for $24 \mathrm{~h}$.

Following the determination of appropriate carbon, nitrogen and phosphate sources, the proper sources for bacteriocin production of each bacterial isolate were used next to six other factors. The factors were $\mathrm{pH}$, temperature, $\mathrm{NaCl}$, trace elements $\left(\mathrm{MnSO}_{4} \cdot 2 \mathrm{H}_{2} \mathrm{O}(14\right.$ ppm), $\mathrm{ZnSO}_{4} \cdot 7 \mathrm{H}_{2} \mathrm{O}(14 \mathrm{ppm}), \mathrm{FeSO}_{4} \cdot 7 \mathrm{H}_{2} \mathrm{O}$ (50 ppm), $\mathrm{CoCl}_{2}(20 \mathrm{ppm})$ ), peptone (as the source of amino acids), and yeast extract (as vitamin and growth factor source) in three levels. The Taguchi orthogonal array was used to analyze the effect of these factors in bacteriocin production in three levels and each experiment repeated three times (Table 1). Taguchi analyses of variance were performed by Minitab 16 Statistical Software.

\section{Results}

\subsection{Bacterial Isolation and Characterization}

Amongst 500 bacterial isolates that put through screening, only two were managed to inhibit the growths of two $X c c$ (isolate NIGEB-K 32 and strain LMG-9671) in disk diffusion assay (Figure 1). Analysis of $16 \mathrm{~s}$ rDNA sequences through BLASTn revealed that one bacterial isolate is Cronobacter (Accession No. JQ999984.1; Figure 2A) and the other is Enterobacter (Accession No. JX308306) (18; Figure 2B). The biochemical characteristics of Cronobacter sp. DGH1 were consistent with other Cronobacters with positive reaction with VP and citrate. The bacterium managed to digest gelatin and was grown on glucose, mannitol and sorbitol with capability of move-

Table 1. Factors and levels used to evaluate bacteriocin production for Taguchi orthogonal array analysis of variance

\begin{tabular}{lccc}
\hline Factors & Level 1 & Level 2 & Level 3 \\
\hline Temperature $\left({ }^{\circ} \mathrm{C}\right)$ & 25 & 35 & 45 \\
$\mathrm{pH}$ & 6 & 7 & 8 \\
Phosphate sourcea $(\mathrm{w} / \mathrm{v})$ & $0.5 \%$ & $1 \%$ & $1.5 \%$ \\
Carbon sourceb $(\mathrm{w} / \mathrm{v})$ & $0.5 \%$ & $1 \%$ & $1.5 \%$ \\
Nitrogen sourcec $(\mathrm{w} / \mathrm{v})$ & $0.5 \%$ & $1 \%$ & $1.5 \%$ \\
$\mathrm{NaCl}(\mathrm{w} / \mathrm{v})$ & $0.5 \%$ & $1 \%$ & $1.5 \%$ \\
Peptone $(\mathrm{w} / \mathrm{v})$ & $0.5 \%$ & $1 \%$ & $1.5 \%$ \\
Yeast extract $(\mathrm{w} / \mathrm{v})$ & $0.5 \%$ & $1 \%$ & $1.5 \%$ \\
Trace elements $(\mathrm{v} / \mathrm{v})$ & $0.1 \%$ & $0.2 \%$ & $0.3 \%$ \\
\hline
\end{tabular}

a: phosphate sources were $\mathrm{Na}_{2} \mathrm{HPO}_{4}$ and $\mathrm{KH}_{2} \mathrm{PO}_{4}$ in case of Cronobacter DGH1 and Enterobacter DGH3, respectively

b: carbon sources were polygalacturonic acid and glucose in case of Cronobacter DGH1 and Enterobacter DGH3, respectively

c: nitrogen sources were $\mathrm{NH}_{4} \mathrm{NO}_{3}$ and $\left(\mathrm{NH}_{4}\right)_{2} \mathrm{HPO}_{4}$ in case of Cronobacter DGH1 and Enterobacter DGH3, respectively 




Figure 1. Disk diffusion assay of two bacterial isolates with their inhibitory effects against Xcc. Cronobacter sp. A: DGH1 supernatant on disk against Xcc isolate NIGEB-K32 and B: strain LMG-9671 and C: Enterobacter sp. DGH3 against Xcc isolate NIGEB-K32 and D: strain LMG-9671. $\mathrm{n}$ is negative control with $0.09 \% \mathrm{NaCl}$ ment. On the other hand, Enterobacter sp. DGH3 demonstrated positive reaction with VP, ONPG and ornithine decarboxylase and use of citrate. Furthermore, it managed to hydrolyze gelatin and grow on xylose, lactose, arabinose, mannitol and sorbitol with moving ability, similar to other Enterobacters. Cronobacter sp. DGH1 was isolated from soil, while Enterobacter sp. DGH3 was isolated from healthy stem parts of a heavily infected plant parts with $X c c$. Further analysis of other Xcc strains and isolates demonstrated that these two bacterial isolates can compromise their growth with 4-18 mm inhibition diameter (data not shown).

UV treatment of bacterial cells, once compared to untreated, has improved the inhibition diameter by 3 and $4 \mathrm{~mm}$ for Cronobacter sp. DGH1 and Enterobacter sp. DGH3, respectively. UV may act as an inducer, probably via weakening the bacterial isolates and alerting cells to start a defense response through producing more bacteriocins.

A

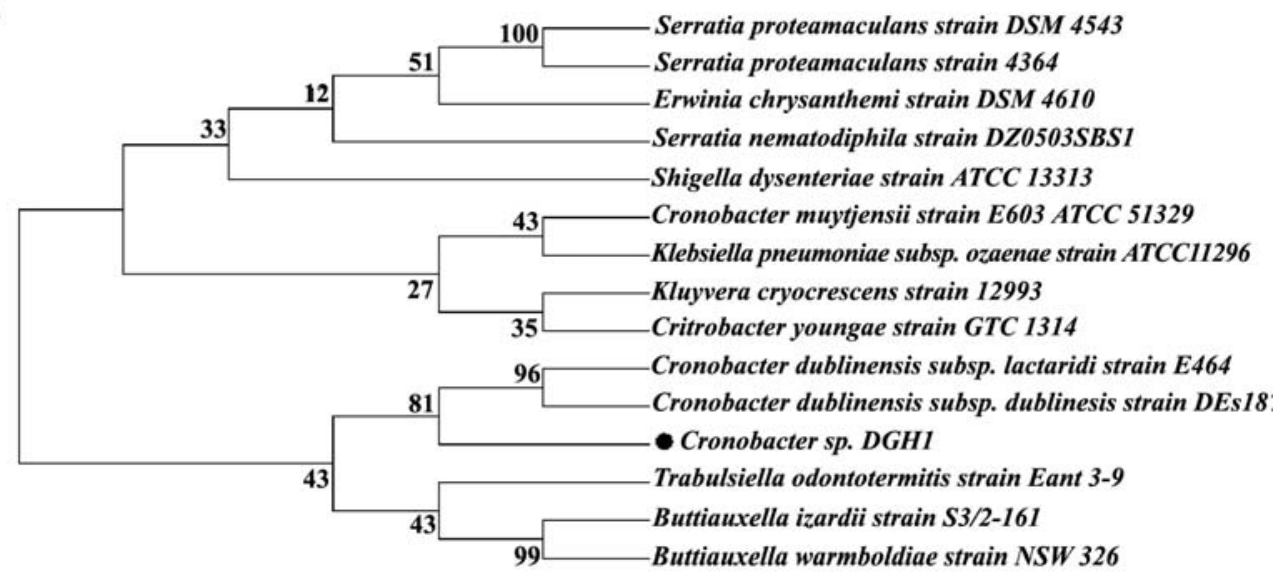

B



Figure 2. Phylogenetic tree of the two bacterial isolates with inhibitory effects on Xcc growth based on 16s rDNA. A: Cronobacter sp. DGH1 grouped well with other Cronobacter species in NCBI, Enterobacter sp. B: DGH3 well grouped with other species of Enterobacter 




Figure 3. Disk diffusion assay of two bacteriocins incubated either in varieties of temperatures or treated with proteases and their inhibitory effects against Xcc. A: Cronobacter sp. DGH1 bacteriocin was incubated at a: 25 , b: 45 , c: 55 , d: 75 , e: $100^{\circ} \mathrm{C}$ for $30 \mathrm{~min}$ on a plate containing Xcc, B: Enterobacter sp. DGH3 bacteriocin was incubated at a: 25 , b: 35 , c: 45 , d: 55 , e: 95 , f: 110 , g: $130^{\circ} \mathrm{C}$ for $30 \mathrm{~min}$ on a plate containing Xcc. C: treatment of Cronobacter sp. DGH1 bacteriocin with a: untreated bacteriocin, b: pepsin, c: trypsin, d: proteinase k. D: treatment of Enterobacter sp. DGH3 bacteriocin with a: untreated bacteriocin, b: trypsin, $\mathrm{c}$ : pepsin, $\mathrm{d}$ : proteinase $\mathrm{k}$, e: papain. $\mathrm{n}$ is negative control with $0.09 \% \mathrm{NaCl}$

\subsection{Bacteriocin Isolation and Characterization}

The two bacteriocins were tested for their inhibition activities against Xcc. The incubated secretomes at different temperatures managed to keep up their inhibition activity up to $55^{\circ} \mathrm{C}$ (Figures $3 \mathrm{~A}$ and $\mathrm{B}$ ). Both treated bacteriocins with various proteases failed to inhibit $X c c$ growth (Figures $3 \mathrm{C}$ and D).

Secretome protein patterns were established via SDS-PAGE and protein bands were recovered from unstained gel and tested for their inhibitory role

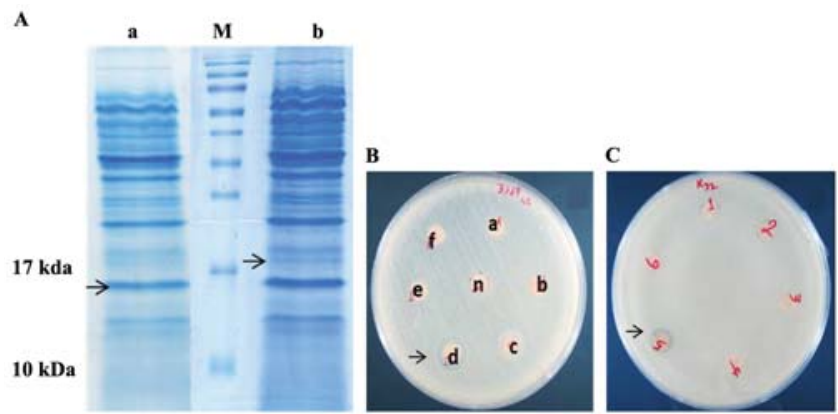

Figure 4. SDS-PAGE analysis of Cronobacter sp. DGH1 and Enterobacter sp. DGH3 secretomes and disk diffusion study of protein bands. A: Secretome protein banding pattern of a: Cronobacter, $\mathrm{M}$ : protein ladder, and $\mathrm{b}$ : Enterobacter. Arrows are indicative of each band that acts as bacteriocin in controlling Xcc. B: Disk diffusion study of some of the Cronobacter sp. DGH1 protein bands, disk d caused inhibition and considered to be bacteriocin. C: Disk diffusion study of some of the Enterobacter sp. DGH3 protein bands, disk 5 caused inhibition and considered to be the bacteriocin

against $X c c$ (Figure 4A). For each bacterial isolate, one band managed to control the $X c c$ growth (Figures $4 \mathrm{~B}$ and $\mathrm{C}$ ). The bands were further analyzed for their activities in varieties of conditions (Table 2). Most proteases and temperatures above $85^{\circ} \mathrm{C}$ inactivated the inhibitory effects of these bands.

The bands were sequenced via MALDI-TOF/TOF and identified as an HCP1 family VI secretion system homologue for Cronobacter sakazakii (YP_001439 956). The peptide fingerprints for Enterobacter sp. DGH3 were $100 \%$ match to pilin FimA of Enetrobacter cloacae subsp. cloacae NCTC 9394 (CBK85798.1; Table 3). Analysis of the sequence via SignalP (19) indicated the presence of a signal peptide leaving a peptide with relative molecular weight of $17 \mathrm{kDa}(20)$, acting as a secretory protein predicted by TargetP (21).

Table 2. MALDI-TOF/TOF de nove peptide fingerprinting of protein bands obtained after SDS-PAGE, being active as bacteriocins. The protein bands were digested with trypsin, reduced and subjected to MALDI-TOF/TOF. The mass data were used to do Mascot search with carbamidomethyl (C) and oxidation (O) as fixed and variable modifications, respectively. Peptide and fragment mass tolerance were set to $\pm 250 \mathrm{ppm}$ and $\pm 0.5 \mathrm{Da}$, respectively

\begin{tabular}{|c|c|c|c|c|}
\hline Bacterial hit & Peptide sequence & $\begin{array}{l}\text { Observed } \\
\text { (Mr) }\end{array}$ & Score & E-value \\
\hline \multirow[t]{3}{*}{ Cronobacter sakazakii } & K.GAETSAGWNIK.E & 1133.5513 & 75 & 0.00085 \\
\hline & K.VNFNDLHVNALIDK.S & 1611.8344 & 110 & $1.4 \mathrm{e}-07$ \\
\hline & K.DSNHTGWTDITSFSWGASQPGNMSVGGGGGAGK.V & 3223.5168 & 270 & $8 e-24$ \\
\hline \multirow[t]{2}{*}{ Enetrobacter cloacae } & K.GELVNAACSVNTDSSEQTVNLGQYR.T & 2712.2573 & 231 & $7.6 e-20$ \\
\hline & K.SSTLTPDGATFSAAQNLIEGTNTLNFTAR.Y & 2998.5271 & 232 & $4.4 e-20$ \\
\hline
\end{tabular}


Table 3. Antibacterial activity and sensitivity to proteases, detergents, range of $\mathrm{pH}$ and temperature, and organic solvents

\begin{tabular}{lccc}
\hline Treatment & Concentration/Time & Cronobacter sp. DGH1 Enterobacter \\
sp. DGH3
\end{tabular}

3.3. Analysis of the Effect of Carbon, Nitrogen and Phosphate Sources on Bacterial Growth and Bacteriocin Production

Generally speaking and considering these two bacteria, it seems that by deteriorating the conditions for bacterial growth, more bacteriocins are being produced. In another word, bacteriocin production is being induced under stress condition more likely as a defense mechanism and probably regardless of stress type, i.e. being biotic or abiotic stress. Major factors that improved either bacterial growth and/or bacteriocin production for each bacterium are being discussed separately in following sections.

Cronobacter DGH1: Among carbon sources, maltose improved bacterial growth while polygalacturonic acid had the least effect. In contrast, polygalacturonic acid had a significant effect on production of bacteriocin, while maltose had little effect. Similarly, the response to the phosphate source was different; bacterium grew well in the availability of $\mathrm{K}_{2} \mathrm{HPO}_{4}$, while highest amount of bacteriocin produced in the presence of $\mathrm{Na}_{2} \mathrm{HPO}_{4}$. Likewise, $\mathrm{NH}_{4} \mathrm{NO}_{3}$ (as the nitrogen source) had the least effect on bacterial growth whereas its effect on bacteriocin production was highest (Figure 5).

Enterobacter DGH3: Glucose and some other sugars improved the bacterial growth very well (Figure 6) and among these sugars, glucose stood up in increasing the amount of bacteriocin. On the contrary, and for nitrogen and phosphate sources the circumstances were different for bacterial growth and bacteriocin production: $\mathrm{NaH}_{2} \mathrm{PO}_{4}$ and $\left(\mathrm{NH}_{4}\right)_{2} \mathrm{SO}_{4}$ improved bacterial growth with little effect on bacteriocin production, while $\mathrm{KH}_{2} \mathrm{PO}_{4}$ and $\left(\mathrm{NH}_{4}\right)_{2} \mathrm{HPO}_{4}$ increased bacteriocin production (Figure 6).

\subsection{Taguchi Analysis of Variance}

In order to determine the factors that may contribute to higher production of bacteriocin in Cronobacter DGH1 and Enterobacter DGH3, nine factors were tested via Taguchi orthogonal array. Moreover, carbon, nitrogen and phosphate sources were used for each bacterium that within preliminary analysis demonstrated to improve bacteriocin production.

Table 4. Taguchi orthogonal array analysis of variance for bacteriocin production of both Cronobacter DGH1 and Enterobacter DGH3

\begin{tabular}{lcccc}
\hline Bacterial isolates & \multicolumn{2}{c}{ Cronobacter } & \multicolumn{2}{c}{ Enterobacter } \\
\hline Factors & MS & F & MS & F \\
\hline Temperature $\left({ }^{\circ} \mathrm{C}\right)$ & 15.138 & $6.65^{*}$ & 53.2231 & $11.02^{* *}$ \\
$\mathrm{pH}$ & 1.739 & $0.76^{\mathrm{ns}}$ & 12.9293 & $2.68 \mathrm{~ns}$ \\
$\left(\mathrm{NH}_{4}\right)_{2} \mathrm{NO}_{3}$ & 1.516 & $0.67^{\mathrm{ns}}$ & - & - \\
$\mathrm{Na}_{2} \mathrm{HPO}_{4}$ & 11.452 & $5.03^{*}$ & - & - \\
$\left(\mathrm{NH}_{4}\right)_{2} \mathrm{HPO}_{4}$ & - & - & 40.9601 & $8.48^{*}$ \\
$\mathrm{KH}_{2} \mathrm{PO}_{4}$ & - & - & 43.7046 & $9.05^{* *}$ \\
$\mathrm{NaCl}$ & 8.767 & $3.85^{\mathrm{ns}}$ & 14.2626 & $2.95 \mathrm{~ns}$ \\
Trace & 9.461 & $4.15^{\mathrm{ns}}$ & 0.3675 & $0.08 \mathrm{~ns}$ \\
Peptone & 13.932 & $6.12^{*}$ & 7.7786 & $1.61 \mathrm{~ns}$ \\
Yeast extract & 3.064 & $1.35^{\mathrm{ns}}$ & 9.7181 & $2.01 \mathrm{~ns}$ \\
Glucose & - & - & 8.0009 & $1.66 \mathrm{~ns}$ \\
Polygalacturonic acid & 3.478 & $1.53^{\mathrm{ns}}$ & & \\
Residual error & 2.277 & & 4.8316 & \\
\hline
\end{tabular}


$\mathbf{A}$

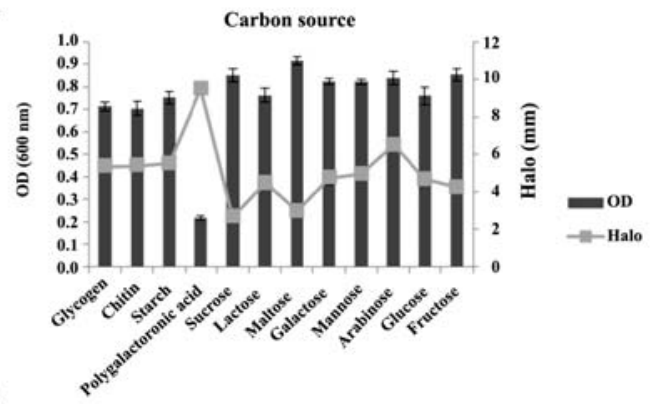

B

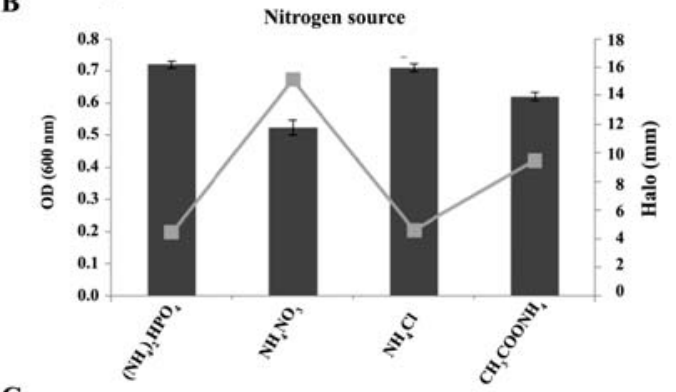

C

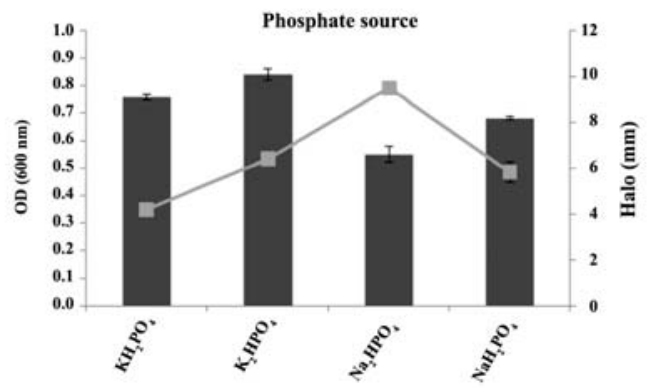

Figure 5. Analyses of the effects of carbon, nitrogen and phosphate sources on Cronobacter DGH1 growth and bacteriocin production. A: Carbon sources (glycogen, chitin, starch, polygalacturonic acid, sucrose, lactose, maltose, galactose, mannose, glucose and fructose) were added to the culture medium individually. Maltose and polygalacturonic acid had the greatest and the least effect on bacterial growth. In contrast, polygalacturonic acid had the highest effect on bacteriocin production. B: Nitrogen sources $\left(\left(\mathrm{NH}_{4}\right)_{2} \mathrm{HPO}_{4}, \mathrm{NH}_{4} \mathrm{NO}_{3}, \mathrm{NH}_{4} \mathrm{Cl}\right.$, and $\left.\mathrm{CH}_{3} \mathrm{COONH}_{4}\right)$ were included within the culture medium separately. $\left(\mathrm{NH}_{4}\right)_{2} \mathrm{HPO}_{4}$ improved the bacterial growth, while $\mathrm{NH}_{4} \mathrm{NO}_{3}$ increased bacteriocin production. C: Phosphate sources $\left(\mathrm{KH}_{2} \mathrm{PO}_{4}, \mathrm{~K} 2 \mathrm{HPO}_{4}, \mathrm{Na}_{2} \mathrm{HPO}_{4}, \mathrm{NaH}_{2} \mathrm{PO}_{4}\right)$ were used in bacterial culture medium alone. $\mathrm{KH}_{2} \mathrm{PO}_{4}$ inclined bacterial growth, while $\mathrm{Na}_{2} \mathrm{HPO}_{4}$ had the little effect. In contrast, $\mathrm{Na}_{2} \mathrm{HPO}_{4}$ improved bacteriocin production

For Cronobacter DGH1, temperature, $\mathrm{Na}_{2} \mathrm{HPO}_{4}$ and peptone demonstrated to have a significant effect on bacteriocin production ( $\mathrm{P}<0.05$; Table 4$)$. Mean comparisons between levels of the significant factors revealed that the highest bacteriocin production was achieved at $25^{\circ} \mathrm{C}, 1.5 \%(\mathrm{w} / \mathrm{v})$ of $\mathrm{Na}_{2} \mathrm{HPO}_{4}$ and $0.5 \%$ $(\mathrm{w} / \mathrm{v})$ peptone. The other factors were statistically
A
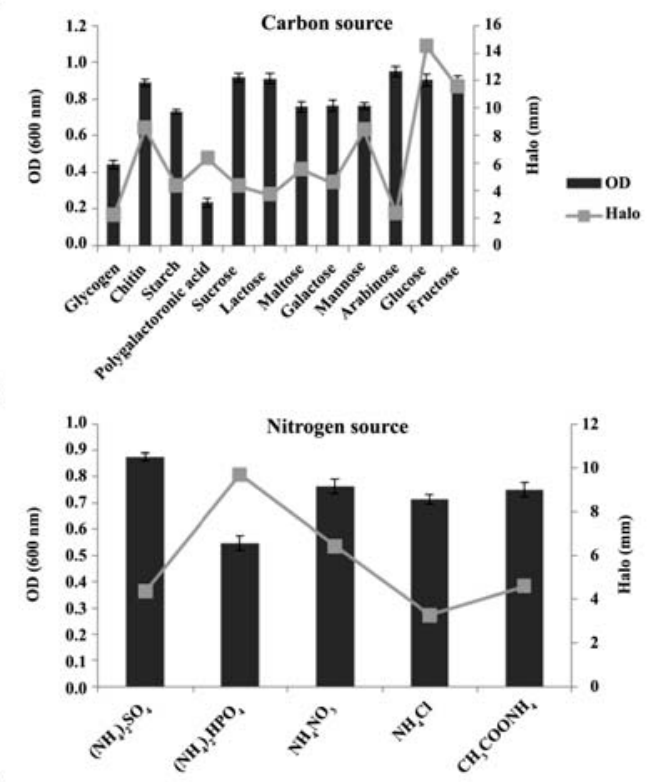

C

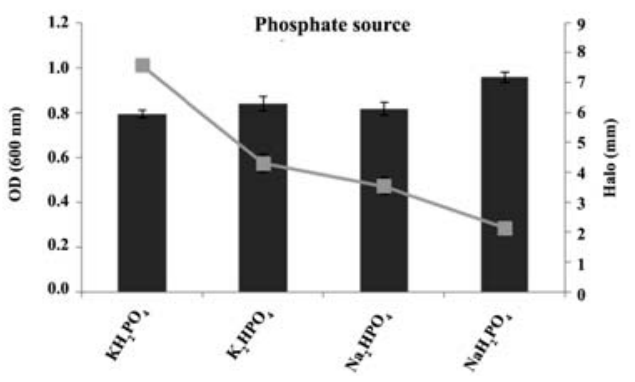

Figure 6. Analyses of the effects of carbon, nitrogen and phosphate sources on Enterobacter DGH3 growth and bacteriocin production. A: Carbon sources (glycogen, chitin, starch, polygalacturonic acid, sucrose, lactose, maltose, galactose, mannose, glucose and fructose) were added to the culture medium individually. Arabinose, glucose, sucrose and lactose improved bacterial growth similarly. The highest bacteriocin production was achieved in the presence of glucose. B: Nitrogen sources $\left(\left(\mathrm{NH}_{4}\right)_{2} \mathrm{HPO}_{4}\right.$, (NH4) ${ }_{2} \mathrm{SO}_{4}, \mathrm{NH}_{4} \mathrm{NO}_{3}, \mathrm{NH}_{4} \mathrm{Cl}$, and $\mathrm{CH}_{3} \mathrm{COONH}_{4}$ ) were included within the culture medium separately. $\left(\mathrm{NH}_{4}\right)_{2} \mathrm{HPO}_{4}$ and $\left(\mathrm{NH}_{4}\right)_{2} \mathrm{SO}_{4}$ decreased and increased the bacterial growth, respectively. For the bacteriocin production the situation was reversed. C: Phosphate sources $\left(\mathrm{KH}_{2} \mathrm{PO}_{4}, \mathrm{~K}_{2} \mathrm{HPO}_{4}, \mathrm{Na}_{2} \mathrm{HPO}_{4}, \mathrm{NaH}_{2} \mathrm{PO}_{4}\right)$ were used in bacterial culture medium alone. $\mathrm{KH}_{2} \mathrm{PO}_{4}$ and $\mathrm{NaH}_{2} \mathrm{PO}_{4}$ improved and decreased bacteriocin production, respectively. The situation was opposite for bacterial growth insignificant and therefore no mean comparison were performed.

For Enterobacter DGH3, temperature, $\left(\mathrm{NH}_{4}\right)_{2} \mathrm{HPO}_{4}$ and $\mathrm{KH}_{2} \mathrm{PO}_{4}$ demonstrated to have a statistically significant role in bacteriocin production. The highest production was achieved at $45^{\circ} \mathrm{C}, 0.5 \%(\mathrm{w} / \mathrm{v})\left(\mathrm{NH}_{4}\right)_{2} \mathrm{HPO}_{4}$ and $1.5 \%(\mathrm{w} / \mathrm{v}) \mathrm{KH}_{2} \mathrm{PO}_{4}$. 


\section{Discussion}

Citrus bacterial canker caused by Xanthomonas citri subsp. citri (22) affects mainly the quality and in severe incidents the citrus production. The disease begins with producing raised lesions on leaves, fruits and stems with oily, water soaked and pustule-like edges surrounding by chlorotic haloes, downgrading the produce $(23,24)$. It develops into leaf abscission, twig dieback and premature fruit drop, reducing tonnage per hectare of citriculture $(25,26)$. Hitherto, in order to control the disease and its impact, IDMS including both cultural practices such as planting wind-breaker trees around the citrus orchards and phytosanitary measures such as the use of copper-containing bactericides or antibiotics and in some areas eradication of inoculum sources have been applied (23). The IDMS has appeared to be costly, less environmentally friendly, and in some cases were impractical. Moreover, the selection pressure through the use of antibiotics and agrochemicals over the bacterial genomes has led to the generation of resistant bacterial isolates (27-29). Therefore and in order to replace or supplement copper-containing chemicals other measures with emphasis on biological control of the disease needs to be taken under consideration (30). Here and for the first time we report on the isolation of two bacterial species with potent anatagoinsitic activities against Xcc growth and further delineation of their bacteriocins, peptides with efficacy on controlling the in vitro growth of $X c c$.

Soil and plant samples were collected from different cities of Sistan-Baluchistan province of Iran on 2010 with emphasis on visiting the affected orchards by $X c c$. Individual colonies (500) were used in disk diffusion assays on plates with cultured LMG-9671 strain and NIGEB-K 32 isolate of Xcc (Figure 1). Amongst which, only two managed to effectively control the Xcc. These two isolates were further analyzed via biochemical means and analysis of their 16s rDNA sequences (Figure 2) and revealed to be a Cronobacter (foodborne bacteria) and an Enterobacter. The secretomes of both bacteria were isolated and their efficacies to control Xcc growth were tested after temperature and protease treatment. These treatments were inactivated the isolated secretome once disk diffusion assay was performed suggesting that the controlling factors are protein in nature. Secretomes were separated on SDS-PAGE (Figure 4) and each and every distinguishable band was extracted from gel and used in disk diffusion assay against $X c c$. One band from each bacterium was managed to control the $X c c$ growth
(Figure 3) that were identified via MALDTI-TOF/TOF as an HCP1 family VI secretion system for Cronobacter sp. DGH1 and pilin FimA for Enetrobacter sp. DGH3. Interestingly, these two proteins appear to be constitutively expressed without the use of any outside inducer.

$\mathrm{HCP}$ family proteins ( $\mathrm{HCP} 1$ and $\mathrm{HCP} 2$ ) next to $\mathrm{VgrG}$ (valine glycine repeat) proteins are parts of type VI secretion system (T6SS) in gram negative bacteria, constructing a needle-like injectisome on the bacterial surface subsequent to their secretion (31-33). This injectisome can puncture the other so called host cell in order to send effector proteins (34). Accordingly, HCP (hemolysin-coregulated protein) proteins do not need to bear a transit peptide for their secretion, something that we have come across through sequence analysis of HCP1. Furthermore and to the best of our knowledge, this is the first report on the presence of T6SS in Cronobacter sp. We believe that through perforating the Xcc membrane by injectisome that HCP1 is part of, the cell content will be released, causing cell death. Moreover it has been shown that HCP1 not only is part of the injectisome, but also is being secreted from the injectisome as a cytotoxic effector causing a cascade of protein responses from the recipient cell that all may lead to cell inflammation and probable rupture (35). In any case, more detailed analysis of the mechanism of action in bacterial recipient cells needs to be addressed in the future.

Pilin FimA is a part of type 1 fimbriae that are fibrillar surface appendages, facilitating mannose-sensitive bacterial interaction with host cells in Enterobacteriaceae $(36,37)$. Fim gene clusters encode these adhesive proteins and assemble them on bacterial surface via the chaperon/usher pathway (38-40). The shaft of this appendage is made up of FimA protein subunits (up to 3,000 copies) with a FimH subunit located right at the tip of the shaft; with specific binding capacity to oligosaccharides with terminal mannose residues $(41,42)$. The involvement of Type 1 fimbriae in pathogenesis of variety of eukaryotic host cells has been demonstrated (43-48), but this is the first report of its involvement in pathogenesis against a prokaryote, namely Xcc. Therefore, in the future studies a detailed analysis of FimA-cell wall interaction seems to be inevitable to delineate the mechanism of action.

In summary, two bacteriocins were isolated and determined that they are capable of killing Xanthomonas citri subsp. citri. Furthermore and through Taguchi orthogonal array, the factors and their 
suitable levels with statistically significant effects on bacteriocin production were determined. Earlier, we have put down a proposal of the direct use of bacterial with controlling ability in the environment to reduce the number of Xcc population. Therefore and in case of medium optimization for higher production of these two proteins, it is suggested to use fine filters to avoid any bacterial intrusion. The other option would be plant transformation with genes encoding these two proteins, i.e. HCP1 and FimA, to investigate plant response to Xcc. However, this approach is more likely dependent on the determination of mechanisms of actions of the proteins. Only feasible remaining option for now would be heterologous expression of these proteins and foliar application over citrus plants preand/or post-inoculation with $X c c$.

\section{Acknowledgments}

We would like to thank National Institute of Genetic Engineering and Biotechnology for the financial support under grant number M406.

\section{References}

1. Messaadia N, Harzallah D. Regulatory effects of Carbon sources on tobtoxin production (a $\beta$-lactam phtotoxin of Pseudomonas syringae pv. tabaci). World Academy of Science, Engineering and Technology. 2011;73:904-908.

2. Ghadbane M, Harzallah D, Laribi A, Jaouadi B, Belhadj H. Purification and biochemical characterization of a highly thermostable bacteriocin isolated from Brevibacillus brevis strain GM100. Biosci Biotechnol Biochem. 2013;77(1):151-160. DOI: 10.1271/bbb.120681

3. Zhang Y, Zhang L, Du M, Yi H, Guo C, Tuo Y, Han X, Li J, Zhang L, Yang L. Antimicrobial activity against Shigella son$n e i$ and probiotic properties of wild lactobacilli from fermented food. Microbiol Res. 2011;167(1):27-31. DOI: 10.1016/j. micres.2011.02.006

4. Wang G, Li X, Wang Z. APD2: the updated antimicrobial peptide database and its application in peptide design. Nucleic Acids Res. 2009;37(Database issue):D933-937. DOI: 10.1093/ nar/gkn823

5. Bayer A, Freund S, Jung G. Post-translational heterocyclic backbone modifications in the 43-peptide antibiotic microcin B17. Structure elucidation and NMR study of a ${ }^{13} \mathrm{C},{ }^{15} \mathrm{~N}-$ labelled gyrase inhibitor. Eur J Biochem. 1995;234(2):414426. DOI: 10.1111/j.1432-1033.1995.414_b.x

6. Duquesne S, Destoumieux-Garzon D, Peduzzi J, Rebuffat S. Microcins, gene-encoded antibacterial peptides from enterobacteria. Nat prod rep. 2007;24(4):708-734. DOI: 10.1039/ B516237H

7. Fath MJ, Zhang LH, Rush J, Kolter R. Purification and characterization of colicin V from Escherichia coli culture supernatants. Biochemistry 1994;33(22):6911-6917. DOI: 10.1021/ bi00188a0 21

8. Garcia-Bustos JF, Pezzi N, Mendez E. Structure and mode of action of microcin 7, an antibacterial peptide produced by Escherichia coli. Antimicrob agents ch. 1985;27(5):791-797. DOI: 10.1128/AAC.27.5.791

9. Jabrane A, Sabri A, Compere P, Jacques P, Vandenberghe I, Van Beeumen J, Thonart P. Characterization of serracin P, a phage-tail-like bacteriocin, and its activity against Erwinia amylovora, the fire blight pathogen. Appl Environ Microbiol. 2002;68(11):5704-5710. DOI: 10.1128/AEM.68.11.57045710.2002

10. Lavina M, Gaggero C, Moreno F. Microcin H47, a chromosome-encoded microcin antibiotic of Escherichia coli. J Bacteriol. 1990;172(11):6585-6588. DOI: 10.1007/978-3642-76974-0_34

11. O'Brien GJ, Mahanty HK. Colicin 24, a new plasmid-borne colicin from a uropathogenic strain of Escherichia coli. Plasmid. 1994;31(3):288-296. DOI:10.1006/plas.1994.1030

12. Poey ME, Azpiroz MF, Lavina M. Comparative analysis of chromosome-encoded microcins. Antimicrob Agents Ch. 2006;50(4):1411-1418. DOI: 10.1128/AAC.50.4.1411-1418. 2006

13. Pons A, Delalande F, Duarte M, Benoit S, Lanneluc I, Sablé $\mathrm{S}$, Van Dorsselaer A, Cottenceau G. Genetic analysis and complete primary structure of microcin L. Antimicrob agents $c h$. 2004;48(2):505-513. DOI: 10.1128/AAC.48.2.505-513.2004

14. Taguchi G. Introduction to quality engineering: Designing quality into process. Tokyo: Asian Productivity Organization.; 1986. DOI: 10.1002 /qre.4680040216

15. Zarei M, Aminzadeh S, Zolgharanein S, Safahieh A, Ghoroghi A, Motallebi A, Daliri M, Lotfi A. Serratia marcescens B4A chitinase product optimization using Taguchi approach. Iran J Biotech. 2011;4:252-262.

16. Tamura K, Peterson D, Peterson N, Stecher G, Nei M, Kumar S. MEGA5: molecular evolutionary genetics analysis using maximum likelihood, evolutionary distance, and maximum parsimony methods. Mol Biol Evol. 2011;28(10):2731-2739. DOI: $10.1093 / \mathrm{molbev} / \mathrm{msr} 121$.

17. Laemmli U. Cleavage of structural proteins during the assembly of the head of bacteriophage T4. Nature 1970;227(5259):680-685. DOI: 10.1038/227680a0

18. Altschul SF, Gish W, Miller W, Myers EW, Lipman DJ. Basic local alignment search tool. J Mol Biol. 1990;215(3):403-410. Epub 1990/10/05. DOI: 10.1016/S0022-2836(05)80360-2

19. Petersen TN, Brunak S, von Heijne G, Nielsen H. SignalP 4.0: discriminating signal peptides from transmembrane regions. Nat methods. 2011;8(10):785-786. DOI:10.1038/nmeth.1701

20. Gasteiger E, Hoogland C, Gattiker A, Duvaud S, Wilkins M, Appel RD, Bairoch A. Protein identification and analysis tools on the ExPASy server. In: Walker J, editor. he proteomics protocols handbook: Humana Press; 2005. p.571-607.

21. Emanuelsson $\mathrm{O}$, Nielsen $\mathrm{H}$, Brunak S, von Heijne G. Predicting subcellular localization of proteins based on their N-terminal amino acid sequence. $J$ Mol Biol. 2000;300(4):1005-1016. DOI: 10.1006/jmbi.2000.3903

22. Schaad NW, Postnikova E, Lacy G, Sechler A, Agarkova I, Stromberg PE, et al. Emended classification of xanthomonad pathogens on citrus. Syst Appl Microbiol. 2006;29(8):690695. DOI: 10.1016/j.syapm.2006.08.001

23. Das A. Citrus canker - A review. J Appl Horticul. 2003;5:52-60. 
24. Schubert T, Rizvi S, Sun X, Gottwald T, Graham J, Dixon W. Meeting the challenge of eradicating citrus canker in Floridaagain. Plant Dis. 2001;85:340-356. DOI: http://dx.doi.org/ 10.1094/PDIS.2001.85.4.340

25. Gottwald T, Graham J, Civerolo E, Barrett H, Hearn C. Differential host range reaction of citrus and citrus relatives to citrus canker and citrus bacterial spot determined by leaf mesophyll susceptibility. Plant Dis. 1993;77(10):1004-1009. DOI: 10.1094/PD-77-1004.

26. Stall R, Civerolo E. Research relating to the recent outbreak of citrus canker in Florida. Annu rev phytopathol. 1991;29:399420. DOI: 10.1146/annurev.py.29.090191.002151

27. Belhu F, Canteros B, Minsavage G, Jones J, Graham J. Molecular characterization of copper resistance genes from Xanthomonas citri subsp. citri and Xanthomonas alfalfa subsp. citrumelonis. Appl Environ Microb. 2011;77:40894096. DOI: 10.1128/AEM.03043-10

28. Belhu F, Jones J, Myers M, Graham J. Monitoring for resistant populations of Xanthomonas citri subsp. citri and epiphytic bacteria on citrus trees treated with copper or streptomycin using a new semi-selective medium. Eur J Plant Pathol. 2012;132:259-270. DOI: 10.?1007/?s10658-011-9870-7

29. Stall R, Loschke D, Jones J. Linkage of copper resistance and avirulence loci on a self-transmissible plasmid in Xanthomonas campestris pv. vesicatoria. Phytopathol. 1986;76:240-243. DOI: 10.1094/Phyto-76-240.

30. Fu XZ, Gong XQ, Zhang YX, Wang Y, Liu JH. Different transcriptional response to Xanthomonas citri subsp. citri between kumquat and sweet orange with contrasting canker tolerance. PloS one. 2012;7(7):e41790. DOI: 10.1371/journal.pone. 0041790

31. Cascales E. The type VI secretion toolkit. EMBO rep. 2008;9(8):735-741. DOI: 10.1038/embor.2008.131

32. Pukatzki S, Ma AT, Revel AT, Sturtevant D, Mekalanos JJ. Type VI secretion system translocates a phage tail spike-like protein into target cells where it cross-links actin. Proc Natl Acad Sci USA. 2007;104(39):15508-15513. DOI: 10.1073/ pnas.0706532104

33. Pukatzki S, Ma AT, Sturtevant D, Krastins B, Sarracino D, Nelson WC, et al. Identification of a conserved bacterial protein secretion system in Vibrio cholerae using the Dictyostelium host model system. Proc Natl Acad Sci U S A. 2006;103(5):1528-1533. DOI: 10.1073/pnas.0510322103

34. Ma L, Zhang Y, Yan X, Guo L, Wang L, Qiu J, Yang R, Zhou D. Expression of the type VI secretion system 1 component Hcp1 is indirectly repressed by OpaR in Vibrio parahaemolyticus. Scientific World J. 2012;2012:982140. DOI: http://dx.doi.org/10.1100/2012/982140

35. Zhou Y, Tao J, Yu H, Ni J, Zeng L, Teng Q, et al. Hcp family secreted via the type VI secretion system coordinately regulate Escherichia coli K1 interaction with human brain microvascular endothelial cells. Infect Immun. 2012;80(3):1243-1251. DOI: 10.1128/IAI.05994-11

36. Duguid J, Anderson E, Campbell I. Fimbriae and adhesive properties in salmonellae. J Pathol Bacteriol. 1966;92:107138. DOI: $10.1002 /$ path. 1700920113

37. Duguid JP, Campbell I. Antigens of the type-1 fimbriae of salmonellae and other enterobacteria. $J$ medic microbiol.
1969;2(4):535-553. DOI: 10.1099/00222615-2-4-535

38. Gerlach GF, Clegg S, Ness NJ, Swenson DL, Allen BL, Nichols WA. Expression of type 1 fimbriae and mannose-sensitive hemagglutinin by recombinant plasmids. Infect Immun. 1989;57(3):764-770. Epub 1989/03/01.

39. Klemm P, Jørgensen B, van Die I, de Ree H, Bergmans H. The fim genes responsible for synthesis of type 1 fimbriae in Escherichia coli, cloning and genetic organization. Mol Gen Genet. 1985;199:410-414. DOI: 10.1007/BF00330751

40. Waksman G, Hultgren SJ. Structural biology of the chaperoneusher pathway of pilus biogenesis. Nat rev Microbiol. 2009;7(11):765-74. DOI: 10.1038/nrmicro2220

41. Jones C, Pinkner J, Roth R, Heuser J, Nicholes A, Abraham S, et al. FimH adhesin of type 1 pili is assembled into a fibrillar tip structure in the Enterobacteriaceae. Proc Natl Acad Sci U $S$ A. 1995;92:2081-5.

42. Thankavel K, Shah AH, Cohen MS, Ikeda T, Lorenz RG, Curtiss R, 3rd, et al. Molecular basis for the enterocyte tropism exhibited by Salmonella typhimurium type 1 fimbriae. $J$ biol chem. 1999;274(9):5797-5809. DOI: 10.1074/jbc. 274.9.5797

43. Abraham S, Shin J, Malaviya R. Type 1 fimbriated Escherichia coli-mast cell interactions in cystitis. J Infect Dis. 2001;183 Suppl 1:S51-55. DOI: 10.1086/318853

44. Althouse C, Patterson S, Fedorka-Cray P, Isaacson RE. Type 1 fimbriae of Salmonella enterica serovar Typhimurium bind to enterocytes and contribute to colonization of swine in vivo. Infect Immun. 2003;71(11):6446-6452. DOI: 10.1128/IAI.71. 11.6446-6452.2003

45. Baorto DM, Gao Z, Malaviya R, Dustin ML, van der Merwe A, Lublin DM, et al. Survival of FimH-expressing enterobacteria in macrophages relies on glycolipid traffic. Nature. 1997;389(6651):636-639. DOI:10.1038/39376

46. Guo A, Lasaro M, Sirard J, Kraehenbühl J, Schifferli D. Adhesin-dependent binding and uptake of Salmonella enterica serovar typhimurium by dendritic cells. Microbiology. 2007;153:1059-1069. DOI: 10.1099/mic.0.2006/000331-0

47. Khan N, Kim Y, Shin S, Kim K. FimH-mediated Escherichia coli $\mathrm{K} 1$ invasion of human brain microvascular endothelial cells. Cell Microbiol. 2007;9:169-178. DOI: 10.1111/j.14625822.2006.00779.x

48. Ponniah S, Abraham SN, Dockter ME, Wall CD, Endres RO. Mitogenic stimulation of human B lymphocytes by the mannose-specific adhesin on Escherichia coli type 1 fimbriae. $J$ Immunol. 1989;142(3):992-998. Epub 1989/02/01. 